研 究

\title{
高周波熱プラズマによる球状銅系サブミクロン粒子の作製
}

小林 法夫的 1.2 , 川上 裕二的 3 , 鎌田 啓嗣的 3 , 李 継光的 1 , 渡辺 隆行的 2 , 石垣 隆正的 1,2

心1 独)物質・材料研究機構 ナノセラミックスセンター, テ 305-0044つくば市並木 1-1.

好 2 東京工業大学 総合理工学研究科 化学環境学専攻, $=226-8502$ 横浜市長津田 4259 .

住友金属鉱山株 新居浜研究所, 干 792-0002 新居浜市磯浦町 17-5.

\section{Spherical Submicron-size Copper and Copper-tungsten Powders Prepared in RF Induction Thermal Plasma}

\author{
Norio Kobayashi ${ }^{\text {th } 1,2}$, Yuji Kawakami ${ }^{\text {th }}$, Keiji Kamada ${ }^{\text {th } 3}$, Ji-Guang Li ${ }^{\text {tै }}$, \\ Takayuki Watanabe ${ }^{\text {2 } 2}$ and Takamasa Ishigaki ${ }^{1,2}$ \\ ${ }_{21}{ }^{1}$ Nano Ceramics Center, National Institute for Material Science, 1-1 Namiki, Tsukuba 305-0044, Japan \\ 42 Department of Environmental Chemistry and Engineering, Tokyo Institute of Technology, 4259 Nagatsuta, Yokohama 226-8502, Japan. \\ ${ }^{3}$ Niihama Reseach Laboratories, Sumitomo Metal Mining Co., Ltd., 17-5 Isoura-cho, Niihama 792-0002, Japan.
}

Received September 5, 2006

\section{SYNOPSIS}

Spherical submicron copper particles were synthesized through evaporation and subsequent condensation of copper powders in $\mathrm{Ar}-\mathrm{H}_{2}$ thermal plasma. Copper powders of $\sim 40 \mu \mathrm{m}$ in size injected into the plasma, evaporated instantly and fine particles were formed through homogeneous nucleation and subsequent heterogeneous condensation. Particle size and the distribution in the synthesized powders were changed depending on the powder feed rate. Formation of submicron size spherical powders attributed to a significantly high degree of supersaturation in a vapor phase. Particle sizes of the as-produced powders range from submicron to several tens of micrometers. A simple sedimentation treatment was successfully applied to separate the as-formed powders with alcohol solvent to give uniform spherical submicron-size particles with monomodal size distributions. $\mathrm{Cu}-\mathrm{W}$ composite powders were synthesized through the $\mathrm{Ar}-\mathrm{H}_{2}$ plasma treatment of $\mathrm{Cu}-\mathrm{WO}_{3}$ composite powders. The starting temperature of shrinkage was made significantly higher than pure $\mathrm{Cu}$ powders by mixing with several wt\% of $\mathrm{W}$.

KEY WORDS

RF thermal plasma, copper powder, submicron-size powder, copper-tungsten composite powder

1 緒言

高周波誘導熱プラズマは 1 万度以上の超高温領域を有し， プラズマ尾炎部で急冷される.そのため, プラズマ中に原料 粉末を注入すると, 高温領域で加熱され蒸発する. プラズマ 尾炎部に輸送された蒸気は, 急冷によって飽和蒸気圧が下が り，過飽和状態で均一核生成が起こる．核生成が起きても依 然過飽和である蒸気はさらに, 生成した核に不均一凝縮し, 粒成長してナノサイズの粒子となる ${ }^{11}$. プラズマ中に鉄など の金属粉末を注入すると, 粒径 $10 \sim 70 \mathrm{~nm}$ のナノ粒子が合成 される ${ }^{2.3)}$. 本研究では, 熱プラズマ中に銅 $(\mathrm{Cu})$ 粉末を供給し 蒸発させ, 気相から微粒子を生成させるプロセスについて検 討した。

銅微粉末の応用として積層セラミックコンデンサ (MLCC) 用内部電極材料や導電ペースト用フィラー材料が考えられる. MLCC は内部電極層と誘電体層とが交互に積層され, 端子電
極で並列に接続された構造を有している. 現在では内部電極 1 層の厚みが $1 \mu \mathrm{m}$, 積層数が数百層程度のものも実用化され ており,内部電極用金属粉末には平均粒径 $0.2 \mu \mathrm{m}$ 程度のニッ ケル $(\mathrm{Ni})$ 微粉末が用いられている。近年, MLCC は小型化, 大容量化が急速に進んでおり，それにともない，内部電極用 金属微粉末の小粒径化も進んでいる.しかし，小粒径の金属 粉末の使用は焼結開始温度が低温化するという問題点を有し ている. MLCC 焼成工程において, 誘電体層の脱バインダが 行われて, 焼結の始まっていない $700^{\circ} \mathrm{C}$ 付近で内部電極層が 急激に収縮すると, 内部電極層と誘電体層に収縮挙動の差が 生じ，層間剥離やクラックなどの構造欠陥の原因となる、そ こで焼結特性の改善, すなわち, 焼結開始温度の高温化が重 要な課題になると考えられる。

本研究では, Niより低コスト, 低環境負荷である $\mathrm{Cu}$ で粒 径 $0.1 \mu \mathrm{m}$ 程度の球状微粉末を作製し, 生成粒子の粒度分布, 
形状を調べた。粉末供給条件を変化させることにより，プラ ズマから固体粒子への熱移動量, 粒子の蒸発量, 気相中の過 飽和度といったプラズマー固体粒子間の相互作用因子が変化 するので, 生成粒子の粒径や粒度分布などの制御が可能となる. また，銅と高融点金属タングステンからなる複合粉末を作製 した，複合化することで収縮開始温度の向上，収縮率の抑制 ができれば，MLCC 内部電極材料として応用が期待できる.

\section{2 実験方法}

プラズマ粉末処理装置はプラズマトーチ (MODEL PL-50 TEKNA Plasma System Inc.), $2 \mathrm{MHz}$ 高周波電源 (日本高周波), 水冷構造反応容器とステンレス製フィルタで構成されている4). $\mathrm{Ar}-\mathrm{H}_{2}$ プラズマを高周波電源に接続されたトーチ内に発生し た. 高純度Arを誘導コイルに垂直方向からセントラルガスと して供給し， $\mathrm{Ar}-\mathrm{H}_{2}$ 混合ガスをシースガスとしてセントラル ガスの周囲に供給した. 原料粉末として銅粉末(電解銅粉, 平 均粒径 $40 \mu \mathrm{m}$, 三井金属鉱業)をキャリアガスと共にト一チ上 部から粉体導入ノズルを通してプラズマ中に注入した. Cu微粉 末作製時のプラズマ発生条件, 原料粉末供給条件をTable 1 (a) に示す．また， $\mathrm{Cu}-\mathrm{W}$ 複合粉末の W源には，金属Wに比べて 低融点の酸化タングステン $\left(\mathrm{WO}_{3}\right.$, 高純度化学研究所) の還元 反応を利用した. $\mathrm{Cu}-\mathrm{WO}_{3}$ 混合粉末のプラズマ処理により $\mathrm{Cu}$ $\mathrm{W}$ 複合粉末を得た. プラズマ発生条件，原料粉末供給条件を Table 1 (b) に示す．主成分となる $\mathrm{Cu}$ に $\mathrm{WO}_{3}$ 粉末を W の割合 が 3, 5, 10, $20 \mathrm{wt} \%$ となるように添加した。この $\mathrm{Cu}-\mathrm{WO}_{3}$ 混合 粉末を $\mathrm{Ar}-\mathrm{H}_{2}$ プラズマ处理することによって複合粉末の合成 を行った。

生成された粉未は酸素濃度 $1 \%$ のアルゴン酸素混合ガス中 で 2 時間徐酸化処理を行った. 生成粉末の多くは反応容器側 面に付着したので, 付着した試料を回収した. 生成粉末は, 原 料が蒸発・凝縮してできたサブミクロンサイズの微粒子と, 原料が蒸発まで至らずに溶融・凝固したミクロンサイズの粗 大粒子の混合粉末であった，そこで，生成粉末をエタノール 中に超音波分散し，沈殿法で微粒子と粗大粒子に分離した。 微粒子部分は走查型電子顕微鏡(SEM)を用いて粒子の形状を 調べ，粒子径の分布を測定した. 1000 個の粒子 1 次粒径を計 測し，粒子を球と仮定して体積基準で累積曲線を描き，累積 曲線の $50 \%$ 径を平均径とした。 また, $\mathrm{Cu}-\mathrm{W}$ 複合粉末は透過 型電子顕微鏡(TEM)で試料の形状観察を行い, エネルギー分

Table 1 Experimental conditions

\begin{tabular}{|l|l|l|}
\hline & \multicolumn{1}{|c|}{ (a) $\mathrm{Cu}$} & (b) $\mathrm{Cu}-\mathrm{W}$ \\
\hline Plate power (kW) & 40 & 40 \\
\hline Reactor pres sure (kPa) & 39 & 39 \\
\hline Central gas (I/min) & $\mathrm{Ar} \mathrm{30}$ & $\mathrm{Ar} \mathrm{30}$ \\
\hline Sheath gas (I/min) & $\mathrm{Ar} 85, \mathrm{H}_{2} 5$ & $\mathrm{Ar} 85, \mathrm{H}_{2} 5$ \\
\hline Carrier gas (I/min) & $\mathrm{Ar} \mathrm{5}$ & $\mathrm{Ar} \mathrm{5}$ \\
\hline $\mathrm{Powder} \mathrm{feed} \mathrm{rate} \mathrm{(g/min)} 0.33,1.7,3.5$ & 1 \\
\hline $\mathrm{WO}_{3}$ additive ratio (wt\%) & 0 & $3,5,10,20$ \\
\hline
\end{tabular}

散型X 線分光(EDS) で組成分析を行った．熱収縮特性は熱機 械分析(TMA)で評価した. TMAでは試料をペレット状 $(\phi 5 \mathrm{~mm}$ $\times \mathrm{t}$ 約 $3 \mathrm{~mm}$ ) に成型し，10 $\mathrm{g}$ の荷重をかけながら， $\mathrm{N}_{2}$ に $2 \%$ の $\mathrm{H}_{2}$ が混合したガス $200 \mathrm{ml} / \mathrm{min}$ 流通下還元雾囲気中で行った.

\section{3 実験結果および考察}

熱プラズマのような急冷プロセスでも, 気相種の濃度が高 く, 高過飽和状態を実現すると, サブミクロンサイズ〜ミク ロンサイズの球状粒子を作製可能である ${ }^{5)}$. 粉末供給速度を 変化させることにより, 銅蒸気濃度を変化させて, 生成粉末 の粒径を制御できると考え, 粉末供給速度による生成粒子の 粒径への影響を調べた。

Fig.1 (a)-(c) に粉末供給速度 0.33, 1.7, $3.5 \mathrm{~g} / \mathrm{min}$ における生
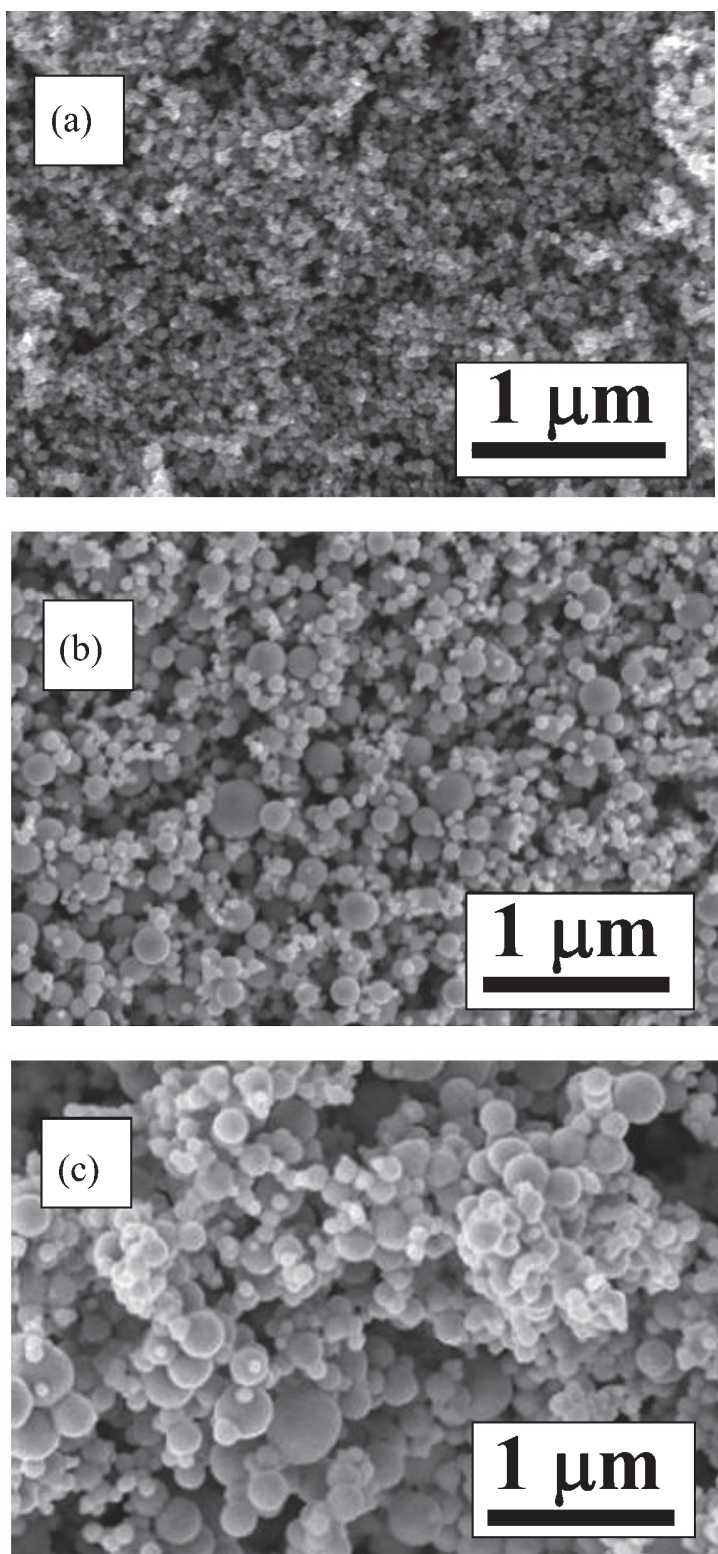

Fig.1 SEM images of the fine copper particles synthesized in $\mathrm{Ar}-\mathrm{H}_{2}$ plasma with various powder feed rates at: (a) $0.33 \mathrm{~g} / \mathrm{min}$, (b) $1.7 \mathrm{~g} / \mathrm{min}$, (c) $3.5 \mathrm{~g} / \mathrm{min}$, respectively. 
成粒子のSEM像を示す.生成した粒子は球状で孤立している ことがわかる. また, 粉末供給速度が増加するに従い, 粒径 は増加した。

Fig.2 (a)-(c) に粒度分布之平均粒径を示す. 粉末供給速度 $0.33,1.7,3.5 \mathrm{~g} / \mathrm{min}$ でそれぞれ0.046, $0.139,0.276 \mu \mathrm{m}$ であった. 平均粒径は粉末供給速度の増加にともなって,ナノサイズか らサブミクロンサイズまで増加した．しかし，供給速度を上 げると粒度分布が拡がり, $3.5 \mathrm{~g} / \mathrm{min}$ では $0.5 \mu \mathrm{m}$ 程度まで成長 する粒子もあった。

Fig.3 に粉末供給速度別の生成粒子の粒径と原料の蒸発割 合, 蒸発量を示す, 粉末供給速度を増加させると, 原料粉末 に加わる単位質量当たりの熱量が減少するので, 蒸発割合は
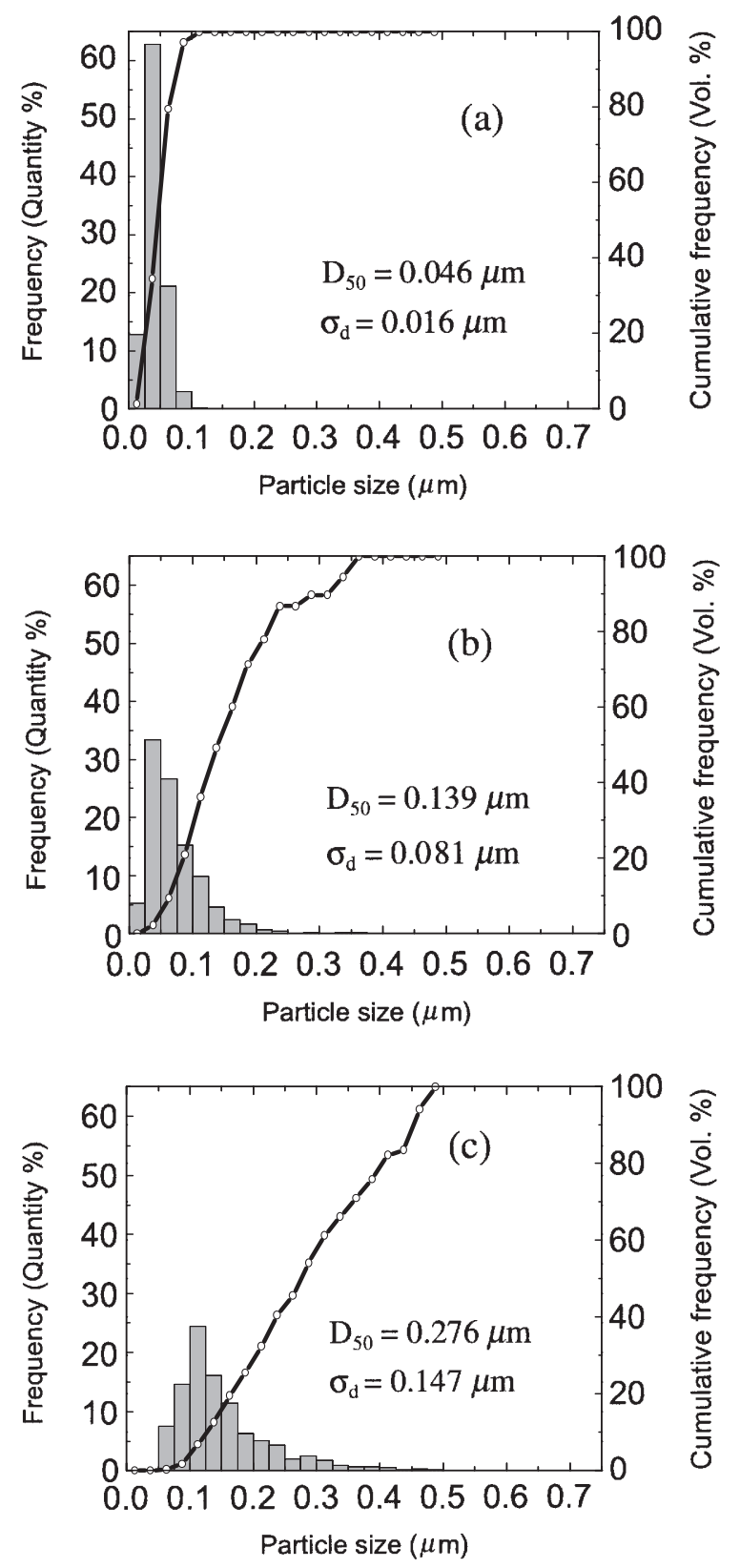

Fig.2 Particle size distribution at various powder feed rate: (a) $0.33 \mathrm{~g} / \mathrm{min}$, (b) $1.7 \mathrm{~g} / \mathrm{min}$, (c) $3.5 \mathrm{~g} / \mathrm{min}$.
減少するが実際に蒸発した量は増加した. 総蒸発量が増加し たため, 気相中の銅蒸気濃度が上昇し, 冷却等により高過飽 和状態となり, 不均一凝縮により粉末供給速度の増加と共に 粒子がより成長したと考えられる。

$\mathrm{Cu}$ と W は約 $3500{ }^{\circ} \mathrm{C}$ 以上では互いに溶融した状態である が, 固相の混合はないのので, $\mathrm{Cu}$ とWは固溶せずに別々に存 在すると考えられる. Fig.4にWO 3 添加量別の生成粉末のXRD を示す. $\mathrm{WO}_{3}$ は蒸発過程でシースガス中の水素で還元されW になった. $\mathrm{Cu}, \mathrm{W}$ の回折ピークに加えて, $\mathrm{CuO}, \mathrm{Cu}_{2} \mathrm{O}, \mathrm{WO}_{3}$ の ピークもみられる. プラズマ処理後の徐酸化処理により生成 粉末の表面は酸化している. 試料中の $\mathrm{WO}_{3}$ 添加量の増加に伴 い, W の割合は増加している. 生成粉末を溶解して ICP 発光 分光分析を行ったところ, 生成粉末之原料粉末の $\mathrm{Cu}, \mathrm{W}$ 組成 はほぼ同じであることを確認した。

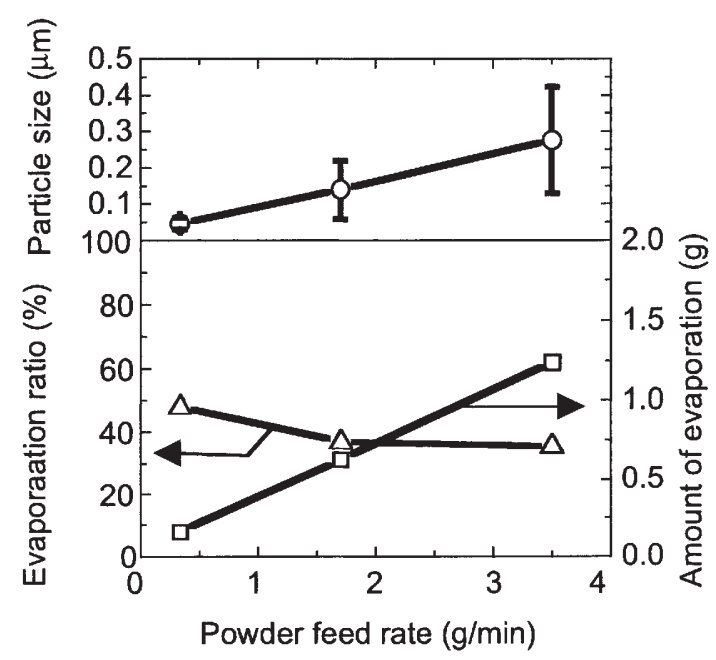

Fig.3 Particle size of fine part powders, amount of evaporation, and evaporation ratio of the raw material at three different powder feed rates.

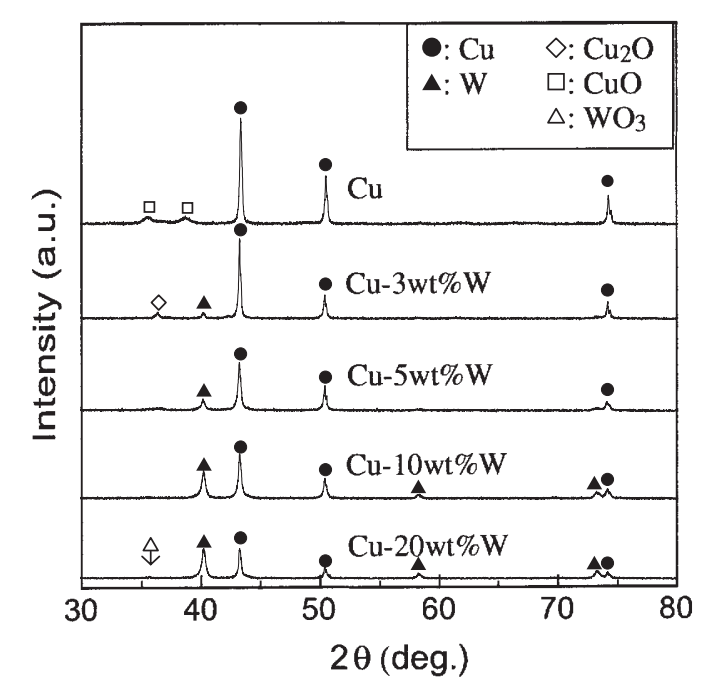

Fig.4 X-ray diffraction patterns of the synthesized powders at different mixing ratio of tungsten powders. 
Fig.5 $\mathrm{KWO}_{3}$ 添加量別の粒度分布を示す. W添加量 $3,5,10$, $20 \mathrm{wt} \%$ の場合の平均粒径はそれぞれ0.052, 0.058,0.061,0.080 $\mu \mathrm{m}$ であった. $\mathrm{Cu}-\mathrm{WO}_{3}$ 混合粉末をプラズマ中に注入すると, 小粒径の $\mathrm{WO}_{3}$ の蒸発によってプラズマの熱が奪われるため, 純銅の場合と比較して蒸発量が減少する. その結果, 生成粒 子は粒径 $0.05 \sim 0.08 \mu \mathrm{m}$ 程度に小さくなる. $\mathrm{WO}_{3}$ の添加量が 増えると, 後で述べるように, Cu粒子の周りに付着するナノ サイズのタングステン粒子が増えるため, 見かけ上粒径が大 きくなった。

銅 (粉末供給速度 $0.33 \mathrm{~g} / \mathrm{min}$ ) を $\mathrm{Ar}-\mathrm{H}_{2}$ プラズマで処理した 場合, 生成粉末は粒径 $0.046 \mu \mathrm{m}$ であるが, $\mathrm{WO}_{3}$ (粉末供給速 度 $1.1 \mathrm{~g} / \mathrm{min}$ ) 単体の場合は, 粒径 $0.023 \mu \mathrm{m}$ のW 粒子が生成し た. プラズマの冷却効果のため, Wの成長する温度領域の体 積が小さくなり, 帯在時間が短いために粒子はナノサイズま での成長に留まった. Fig.6, Fig.7にW 添加量 3,20 wt\% の生 成粉末の TEM 像と EDSによる組成分布, SEM 像を示した. EDSからタングステン添加量 3wt\%において, サブミクロン サイズの $\mathrm{Cu}$ 粒子表面にナノサイズのタングステン粒子が 所々に付着していた，添加量 $20 \mathrm{wt} \%$ においては，銅粒子の表 面はタングステン粒子に覆われていた. プラズマ中で蒸発し た $\mathrm{Cu}$ と W は, 尾炎部の冷却過程において別々に凝縮し, 夕 ングステンが銅の表面に析出した.

Fig.8にTMAによるW添加量別の熱収縮率変化を示す. 比 較として平均粒径 $0.1 \mu \mathrm{m}$ 程度の純銅粉末の測定も行った. W は Cuよりも融点が高く焼結温度も高い. Cu粒子の表面にW が存在すると焼結を阻害するので, W 添加量が多いほど熱収 縮率を抑制できた。純銅粉末の場合には, $340^{\circ} \mathrm{C}$ の比較的低 温から収縮が開始されるのに対し，W 添加量が 3, 5, 10, 20 wt\%の場合は粒径が小さいにもかかわらず, それぞれ $400^{\circ} \mathrm{C}$, $430^{\circ} \mathrm{C}, 490^{\circ} \mathrm{C}, 680^{\circ} \mathrm{C}$ あたりから収縮した. 添加量と共に収縮 開始温度が高温側へ移行していることがわかる.W添加量が わずか $3 \mathrm{wt} \%$ で純銅粉末に比べて収縮開始温度が数 $10{ }^{\circ} \mathrm{C}$ 上 昇したので, Wが焼結開始温度を高くするのに効果があるこ とが示された.

\section{4 ま と め}

本実験では, 生成粒子の粒径変化が原料のプラズマ中の蒸 発量に対応していることを確認し, 原料Cu粉末の供給速度を 増加させることで, 銅の蒸気濃度が増加し, 銅微粉末を粒径 $0.1 \mu \mathrm{m}$ 程度まで成長させることができた (粉末供給速度 : 1.7 $\mathrm{g} / \mathrm{min}$, 圧力: $39 \mathrm{kPa}$, 水素流量 $5 \mathrm{l} / \mathrm{min})$. このようなサブミク ロンサイズの球状銅微粉末は, 導電ペースト用フィラー材料 などで使用できる.

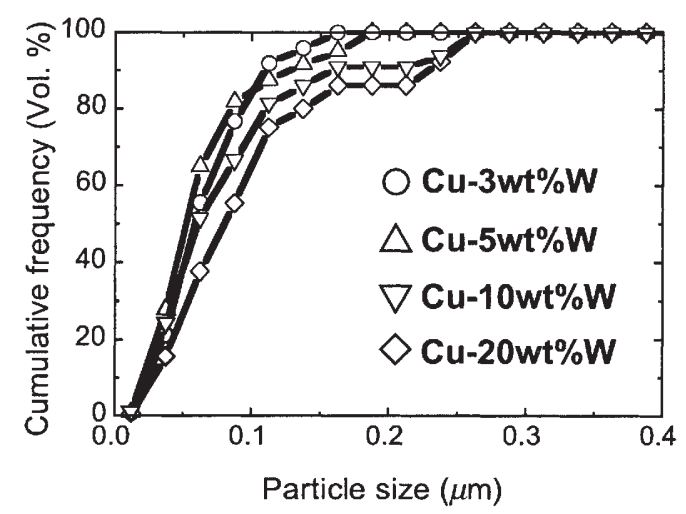

Fig.5 Particle size distribution of the synthesized powders at different mixing ratio of tungsten powders.
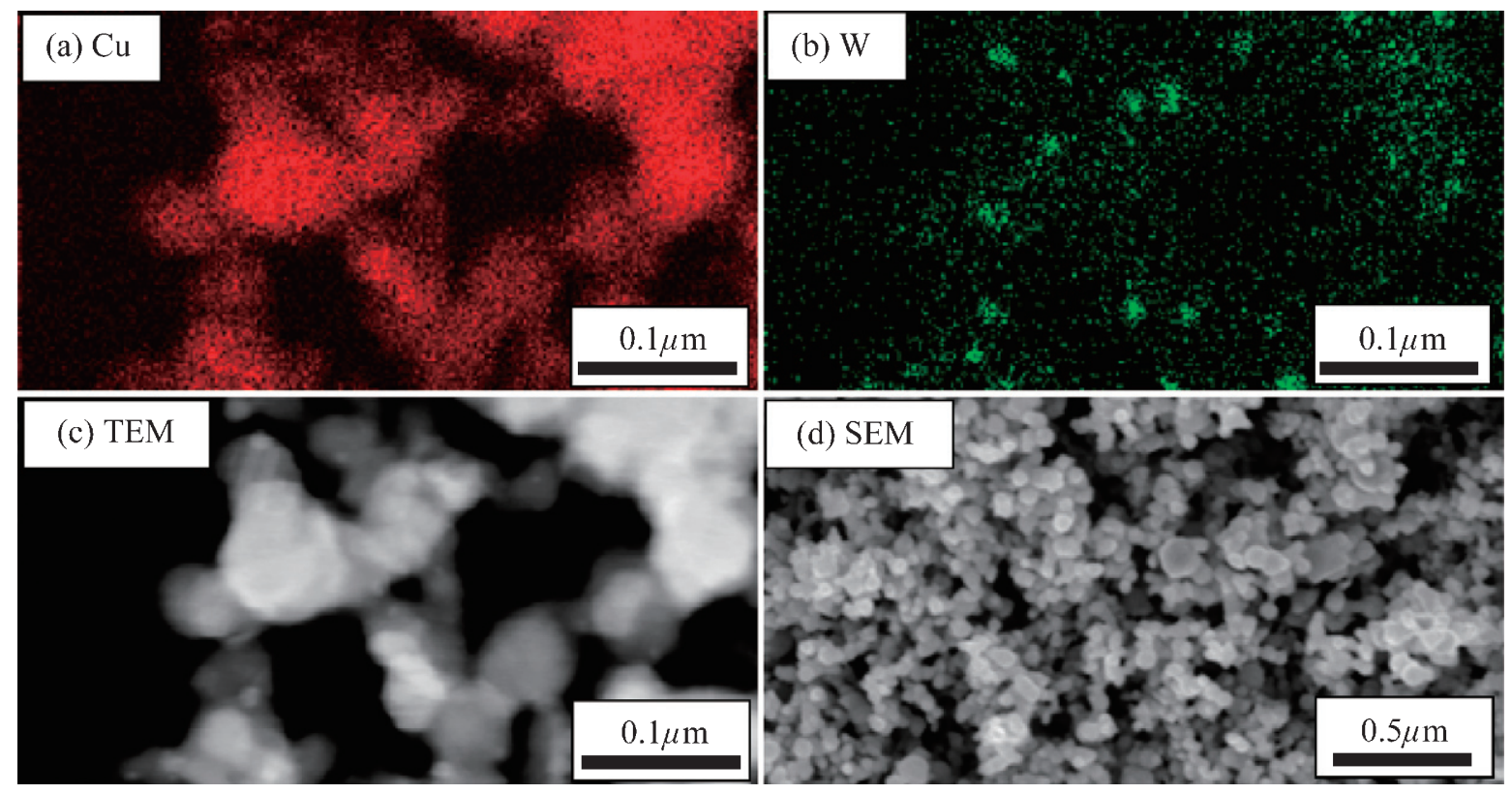

Fig.6 (a), (b) Charactaristic X-ray image mapping by TEM /EDS of the synthesized powders at Cu-3wt\% W, (c) TEM image of and (d) SEM image of the synthesized powder. 


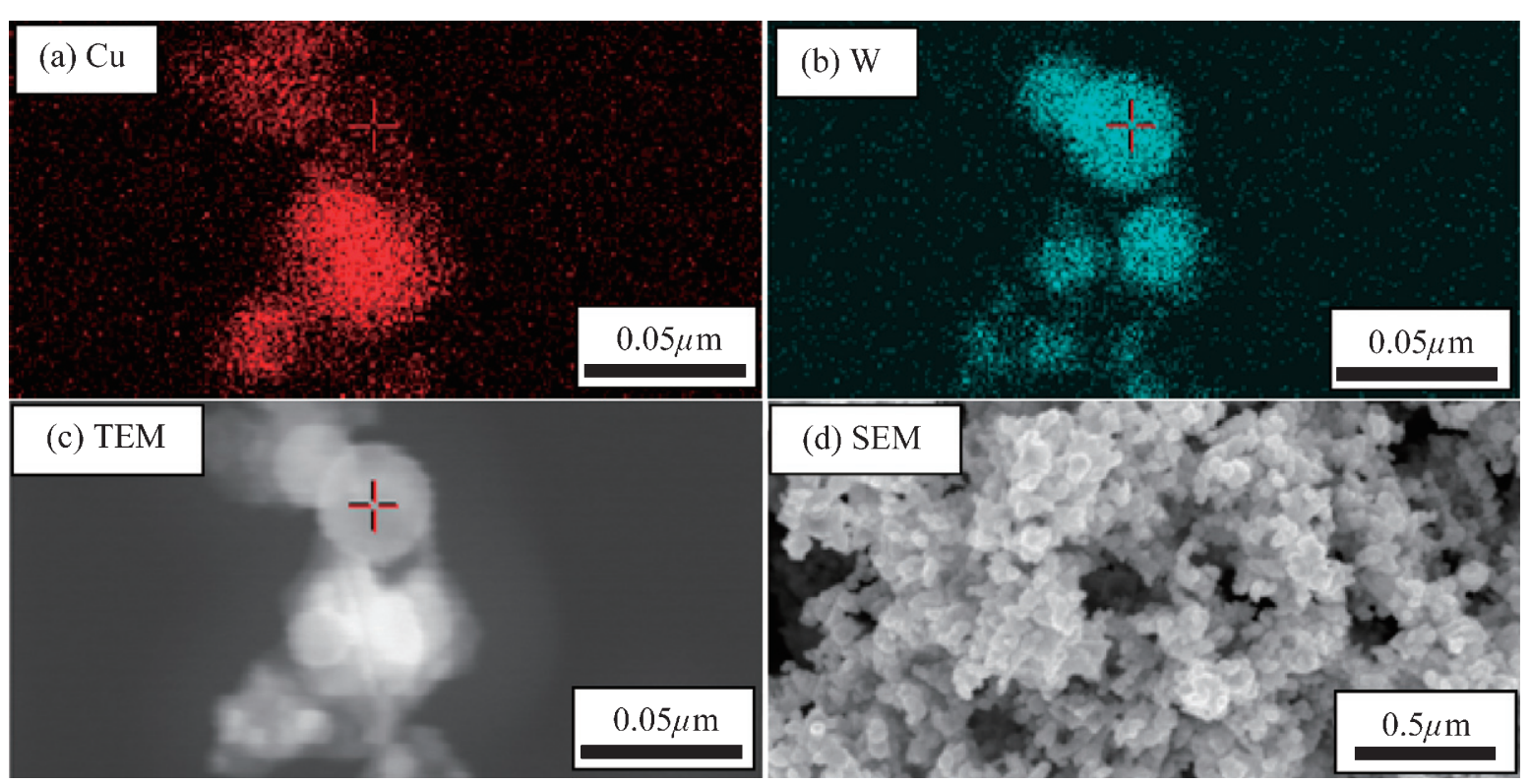

Fig.7 (a), (b) Charactaristic X-ray image mapping by TEM /EDS of the synthesized powders at Cu-20 wt\% W, (c) TEM image of and (d) SEM image of the synthesized powder.

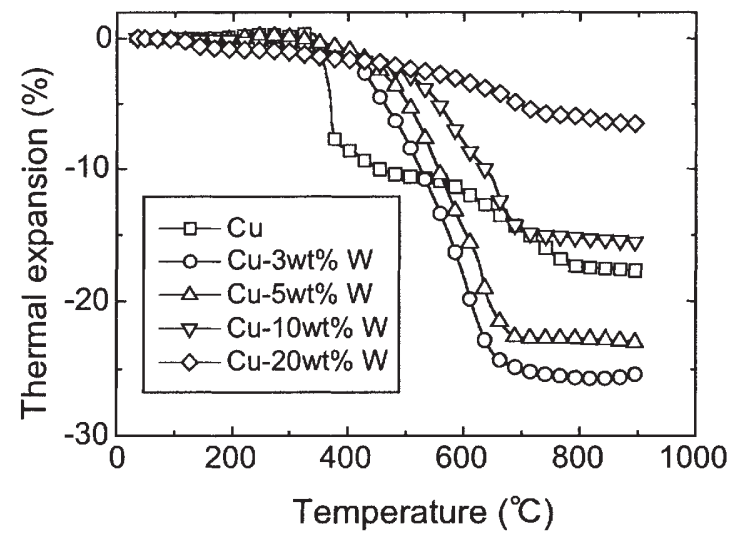

Fig.8 Shrinkage of $\mathrm{Cu}-\mathrm{W}$ composite powders.

$\mathrm{Cu}$ とW 複合化することで，熱収縮開始温度を純銅より も高温側に移行でき，収縮も抑制できることを示した. $\mathrm{Cu}$ と $\mathrm{W}$ は融点が著しく異なるので, 生成粉末は粒径 $50 \sim 80 \mathrm{~nm}$ の $\mathrm{Cu}$ 粒子表面に, 粒径 $10 \mathrm{~nm}$ 程度のWナノ粒子が付着した構造 であり, 粒界に存在するWが $\mathrm{Cu}$ 粒子の焼結を阻害するため, 熱収縮特性を制御できるようになった．MLCCの製造過程に おいてセラミックス誘電体層と内部電極層の熱収縮開始温度,
熱収縮率の不一致がコンデンサの層間剥離やクラックをもた らすが，Cu とW 複合化することにより熱収縮特性の制御 が可能となり, MLCC 電極材料への応用が期待できる.

\section{文献}

1) M.Shigeta, T.Watanabe and H.Nishiyama: "Numerical Investigation for Nano-particle Synthesis in an RF Inductively Coupled Plasma", Thin Solid Films., 457(2004)192-200.

2) T.Yoshida and K.Akashi: "Preparation of Ultrafine Iron Particles using an RF Plasma", Materials Transactions, JIM., 22(1981) 371-378.

3) S.L.Girshick, C.-P.Chiu, R.Muno, C.Y.Wu, L.Yang, S.K.Singh and P.H.McMurry: "Themal Plasma Synthesis of Ultrafine Iron Particles", J. Aerosol Sci., 24(1993)367-382,

4) Y.-L.Li and T.Ishigaki: "Spheroidization of Titanium Carbide Powders by Induction Thermal Plasma Processing", J. Am. Ceram. Soc., 84(2001)1929-1936.

5) Y.-L.Li and T.Ishigaki: "Synthesis of Crystalline Micron Spheres of Titanium Dioxide by Thermal Plasma Oxidation of Titanium Carbide", Chem. Mater., 13(2001)1577-1584.

6) T.B.Massalski: Binary Alloy Phase Diagrams, Second Edition Vol. 2. ASM International, (1990) 1504. 